\title{
Společensko-kritické aspekty české metafyzické detektivky
}

\author{
Michaela Paučo
}

\begin{abstract}
The Czech metaphysical detective novel and its socio-critical aspects

The metaphysical detective novel is a non-forged genre in the Czech literary world. In this short study, therefore, we try to introduce the specifics of this genre briefly, then we deal with its different varieties presenting a socio-critical overlap. Focusing on strategies of investigation and social critique, we analyze works by Czech authors Radka Denemarková, Václav Kahuda, Miloš Urban, and Patrik Ouředník. In conclusion, we demonstrate that social critique represents important and often manifest aspiration of contemporary Czech metaphysical detective novel.
\end{abstract}

\section{KEYWORDS}

Metaphysical detective story; Contemporary Czech novel; Socio-critical literature.

\section{KLÍčOVÁ SLOVA}

Metafyzický detektivní román; současná česká próza; společensko-kritická próza.

\section{Detekce jako nástroj ke společenské kritice}

Detektivka namířená na kritiku společnosti, fungování úřadů a státního aparátu je často asociována s americkou školou hard-boiled, tedy drsnou školou, jejímiž hlavními představiteli jsou Dashiell Hammett a Raymond Chandler. V nebývalé míře se politická i sociální kritika stala součástí severských detektivních románů, které se svým efektivním prolnutím žánrů detektivky, společenského románu a thrilleru staly celosvětovým fenoménem. Společenská kritika je sou- 
částí také současné české detektivní literatury - v roce 2013 napsala začínající autorka Nela Rywiková novelu Dům číslo 6, v níž policista pátrá po nezvěstném muži v nehostinném prostředí vítkovických železáren. Tuto detektivku můžeme zároveň považovat za „sondu či beletristickou studii jedné zmarněné etapy, kroniku socialistického plánování a jeho zhoubného dopadu na mnohá manželství, dětství, generace" (KUBÍČKOVÁ 2013). V pozadí vraždy docenta Chalupy v románu Michala Sýkory Modré stíny zase stojí tunelování veřejných prostředků a evropských dotací na univerzitní půdě. Korupce ve vysoké české politice vyprovokovala i populárního českého spisovatele Michala Viewegha, který je autorem dvou společensko-kritických thrillerů Mafie v Praze (2011) a Mráz přichází z Hradu (2012).

V tomto př́ispěvku se ovšem nebudeme zaobírat populární detektivkou, která se více méně drží zavedených narativních postupů detektivního žánru. Naším cílem je představit společensko-kritické aspekty těch románů, které se tradiční představě o detektivce vymykají. Pravidla hry porušovala už sama Agatha Christie a také hard-boiled detektivky dokazují, že se autoři nehodlali spokojit s „pouhým“ stopováním vraha a obohacovali pátrání o společensko-kritický rozměr. K výrazné transgresi žánru došlo ještě během druhé světové války, kdy Jorge Luis Borges napsal povídku Zahrada, v níž se cestičky rozvětvují (1942). V tomto krátkém textu Borges ukotvuje převrácený detektivní postup, který o něco málo později rozvine v povídce Smrt a kompas (1942). At už pátrání po smyslu díla či hledání vraha, porozumění vždy doprovází neodvratitelná smrt. Povídku Zahrada, v níž se cestičky rozvětvují, která by mohla připomínat i špionážní thriller, označil Borges ve svém prologu souboru povídek Fikce za detektivní příběh. Ustálená forma detektivky je tu však postavena naruby: vražda se přihodí až na konci, čtenář nepátrá po pachateli, ale po zdůvodnění, zločin „řešíme“ jen pár vět po jeho vykonání. Dle Briana McHalea se Borgesovi díky odmítnutí „původního“ textu prostřednictvím techniky meta-textu podařilo vytvořit nový, originální fikční narativ (McHALE 1987: 48).

Tímto novým fikčním narativem je právě metafyzický detektivní příběh ${ }^{1}$, jímž se budeme v této studii zaobírat, potažmo jeho určitými (společensko-kritickými) aspekty v českém kontextu. Vzhledem k tomu, že termín „metafyzický detektivní příběh" (požíváme také sousloví metafyzický detektivní román, či zkráceně metafyzická detektivka) není v české literárněvědné terminologii příliš vžit,

1) Termín metafyzický detektivní příběh přebíráme z antologie Detecting Texts. The Metaphysical Detective Story from Poe to Posmodernism od Patricie Merivale a Susan Elizabeth Sweeney (1999). 
nastíníme krátce základní principy tohoto subžánru², často spojovaného s postmoderní poetikou. Metafyzická detektivka totiž velmi dobře odráží problémy postmoderní společnosti spojené s kapitalismem, globalizací, ztrátou originálu. V zahraniční literatuře tato témata otevírají renomovaní autoři jako Paul Auster, Umberto Eco, Don DeLillo, Thomas Pynchon, Antonio Tabucchi. V románech těchto autorů najdeme témata jak společenská, tak ta niterná, jako pátrání po identitě člověka.

\section{Principy metafyzického detektivního románu}

Zásadním zdrojem k uchopení metafyzické detektivky je antologie od Patricie Merivale a Susan Elizabeth Sweeney. Detecting Texts: The Metaphysical Detective Story from Poe to Postmodernism z roku 1999 je prvním sborníkem textů, který se fenoménem metafyzické detektivky systematicky zabývá. Termín „metafyzický detektivní př́běh" autorky přebírají od Howarda Haycrafta, který jej užil pro Chestertonův odlišný př́istup k žánru s filozofickou akcentací již v roce 1941 v knize Murder for Pleasure: The Life and Times of Detective Story. Termín byl poprvé odborně definován v roce 1967 Patricií Merivale v kritické eseji o detektivní tvorbě Nabokova a Borgese The Flauting of Artifice in Vladimir Nabokov and Jorge Luis Borges. ${ }^{3} \mathrm{~V}$ sedmdesátých a osmdesátých letech pak vyšlo několik příspěvků zabývajícími se postmoderními manipulacemi s žánrem, někteří autoři přitom pracovali s označením „metafyzická detektivka“ (Michael Holquist - Whodunit and Other Questiones: Metaphysical Detective Stories in Post-War Fiction, 1971), jiní nacházeli ekvivalent v označení „postmoderní (William V. Spanos - The Detective and the Boundary: Some Notes on the Postmodern Literary Imagination, 1972). Významnou souhrnnou studií povahy metafyzických detektivních příběhů je práce Stefana Taniho ${ }^{4}$ The Doomed

2) V připravované disertační práci zaobírající se českou variantou metafyzického detektivního románu zvažujeme, zda pojímat metafyzický detektivní román jako samostatný žánr, subžánr žánru detektivního, nebo jako modus - tedy detektivní román vyznačující se určitými vlastnostmi (absence rozuzlení, poražený detektiv, ontologické otázky a dále). Metafyzický detektivní román, přestože převrací pravidla detektivního žánru a vykazuje množství specifických znaků, považujeme za subžánr, tedy žánr vycházející z detektivky klasické, kterou podvrací. Dle Petř́icka ovšem není metafyzická detektivka pokračováním, tedy navazující fází žánru, nýbrž jeho transgresí (PETŘíČEK 2000: 171).

3) Esej vyšla ve sborníku Nabokov: The Man and His Work. Madison: University of Wisconsin Press, 1967, s. 290-324.

4) Stefano Tani pracuje s termínem anti-detektivka, který významově vyhovuje detektivce metafyzické, ovšem dle Merivale \& Sweeney předznamenává negativní konotaci vůči původním strategiím žánru a nepovažují proto tento termín za vhodný. $Z$ tohoto důvodu se přikláníme k termínu „metafyzický detektivní román“. 
Detective: The Contribution of the Detective Novel to Postmodern Italian and Amerian Fiction (1984).

Metafyzický detektivní příběh zaujímá ke klasické detektivce subverzivní vztah - záměrně porušuje obligatorní narativní pravidla a mechanizmy, jako např́klad „čtenářsky uspokojivý“ závěr (tedy osvětlení, rozřešení detekce) nebo vstřícný přístup ke čtenáři, který by měl mít stejnou šanci vyřešit případ jako fikční detektiv. Společně s Patricii Merivale a Susan Elizabeth Sweeney můžeme definovat metafyzický detektivní příběh následovně: „Metafyzický detektivní příběh je text, který paroduje nebo subvertuje konvence tradičního detektivního příběhu - jakým je uzavření narativu či role detektiva jako náhradníka za čtenáře - a to s úmyslem pokládání si otázek o tajemství bytí a vědění, jež transcendují pouhou mechaničnost detektivního příběhu. Tato transcendence je v metafyzické detektivce často zdůrazněna sebereflexivitou“"5 (MERIVALE SWEENEY 1999: 2).

Metafyzický detektivní román stojí v mnohem větší míře na ontologii, nežli empirii. Př́klon k ontologickým otázkám v postmoderních textech zdưrazňuje Brian McHale, svá tvrzení pak v několika případech opírá právě o metafyzické detektivní romány, někteří teoretici pojmenovávají metafyzickou detektivku jako ontologickou (Elana Gomel). V metafyzickém detektivním příběhu není důležité rozuzlení, naopak - detektiv, obklopen nesmyslnými klíči, ve svém pátrání často selhává. Vražda nemusí být nutně přítomna - novým předmětem pátrání bývá vlastní identita, zmizelá osoba či tajemný dvojník. Šetření může být založeno na falešné domněnce a př́ípad se tak ukazuje jako nesmyslný. Hlavním principem metafyzického detektivního románu je podstata samotné detekce, nikoliv její rozřešení. Toto nové uvažování nad detektivním žánrem dobře ilustruje tvrzení Borgesova vypravěče v povídce Abenchákán Bochárí, který byl zabit ve svém bludišti, tedy že vyřešení zločinu je vždy mnohem méně zajímavé než tajemství samo6 (BORGES 1999: 306).

Zahraniční metafyzická detektivka myšlenkově výrazněji navazuje na samotného předchůdce hard-boiled detektivky, tedy na méně známou povídku Edgara Allana Poea Muž v davu (1840), v níž vypravěče zaujme neznámý podivín

5) A metaphysical story is a text that parodies or subverts traditional detective story conventions - such as narrative closure and the detective's role as surrogate reader - with an intention, or at least the effect, of asking questions about mysteries of being and knowing which transcend the mere machinations of the mystery plot. Metaphysical detectives stories often emphasizes this transcendence, moreover, by becoming self-reflexive. (Tuto i další angl. pasáže přel. M. P.)

6) „Dunraven si jakožto čtenář detektivních románů pomyslil, že rozluštění záhady se nikdy nevyrovná záhadě samé.“ 
a začne enigmatický přízrak v přeplněných ulicích města sledovat. Pátrání ovšem nikam nevede podobně jako v románech Kóbó Abeho (Tvář toho druhého, 1964) nebo Paula Austera (Newyorská trilogie 1985, 1986, 1986), v jejichž románech se tato Poeova poetika nepochybně odráží. Tento typ metafyzické detekce má blízko k solipsismu, představuje temnotu osamělého detektiva, jehož pově-

(1) domí o vlastní identitě se postupně zamlžuje. Nejpregnantnějším představitelem metafyzické detektivky v české literatuře je Michal Ajvaz, který v mnohém navazuje na zakladatele žánru Jorge Luise Borgese. Podobně jako Borges také Ajvaz svou prózou vytváří alternativní možné světy, které jsou založeny na nekonvenčních způsobech vnímání. Ajvazovy detektivní příběhy (Prázdné ulice 2004, Cesta na jih 2008), jsou nasyceny odkazy na fenomenologii, sémiotiku, otázkami po smyslu umění. Přesto dokáží zaujmout i méně poučeného čtenáře - Ajvaz umně prolíná rovinu filozofickou s dobrodružným vyprávěním plným fantaskních motivů.

\section{Možnosti české detektivky}

Česká literatura dokázala na zahraniční tendence odpovědět i za éry socialismu. Pod nálepkou „detektivní literatura“ se Josefu Škvoreckému dařilo skrývat kritiku poměrů v tehdejším socialistickém Československu (Lvíče 1969, Mirákl 1972 v exilovém vydání). Poněkud překvapivě bychom v tomto kontextu mohli uvést literární dílo Ladislava Fukse Vévodkyně a kuchařka z roku 1983, v němž autor sleduje nekonvenční jednání vévodkyně Sophie. Přestože se jedná především o vpravdě groteskní výpověd’ o končící habsburské monarchii, doprovází hlavní vyprávěcí linku všudypřítomné tajemno, které vévodkyni značně interesuje a pátrá po jeho přícinách (jak zemřel její bratr? co způsobuje podivné zvuky v klekátku? co vévodkyně zamýšlí s dutým prstenem?). Fuks zde spíše komickou nežli kritickou formou nahlíží na prostředí upadající šlechty a vyprávění doplňuje o esejistické úvahy o chudobě, historii a konci Rakouska-Uherska. Neodvažujeme se dávat toto Fuksovo dílo do přímého vztahu s detektivní literaturou, nicméně považujeme je za velmi důležité pojítko mezi postmoderním uvažováním a motivem detekce jakožto podstatným fabulačním hybatelem. Metafyzický detektivní román bychom mohli jednoduše považovat za žánr symptomatický právě pro postmoderní éru, ovšem ve světové literatuře je živý a uplatňovaný stále, $v$ české literatuře, řekněme, s mírným zpožděním, taktéž. Po roce 1989 se detektivním žánrem inspirovali autoři jako Roman Ludva, Jiří 
Kratochvil, Jan Jandourek nebo Miloš Urban. U posledního jmenovaného se pak detektivní žánr ve své postmoderní transformaci stal prostředkem ke společenské angažovanosti.

Až na přelomu prvního a druhého desetiletí nového milénia můžeme sledovat větší počet angažovaných próz s detektivní zápletkou. Kateřina Tučková v historicky laděném románu reflektuje manipulaci s člověkem za éry socialismu (Žitkovské bohyně 2012), podobně již dřive Jiří Hájíček v Selským baroku (2005). V roce 2014 vychází Př́spěvek k dějinám radosti Radky Denemarkové, který otevřeně spílá netečnosti společnosti vůči násilí na ženách. Fantaskně-detektivní próza Petra Stančíka Mlýn na mumie (2014) otevírá témata jako nesmyslná krutost válek a prospěchářství člověka, který dokáže zpeněžit všelicos, i lidské ostatky. Ve stejném roce vychází také kniha Marka Tomana Veliká novina o hrozném mordu Šimona Abelese, která zpracovává starou legendu o úmrtí malého židovského chlapce. $V$ případu ze 17. století hraje značnou roli manipulace médií, jež upravují informace tak, aby útočily na emoce.

Světově proslulým metafyzickým detektivním románem se stalo Jméno růže Umberta Eca, jež povrchně připomíná román Miloše Urbana Sedmikostelí. Romány spojuje motiv brutálních vražd vykonaných ve jménu vyšších idejí. Matyáš Gmünd (Sedmikostelí) chce vrátit Praze její starou tvář a společnosti řád, strážce knihovny Jorge z Burghosu (Jméno růže) se snaží zabránit uvolňování morálky mnichů. Ve Jménu růže dojde k odhalení vraha náhodou, v Sedmikostelí se mladý policista Květoslav Švach přidává na stranu vraha, obnovitele středověkých ideálů. I další detektivní romány Miloše Urbana (Santiniho jazyk, Stín katedrály, Boletus arcanus, Přišla z moře) zaujímají inovativní přístup vůči žánru a současně jsou otevřeně kritické vůči morálním hodnotám české společnosti.

Také opus magnum Vítr, tma, př́tomnost (2014) zahajuje vypravěč Václava Kahudy pátráním po nevyjasněných osudech svého dědečka, které se v procesu vyprávění zvrátí v kritické, až konspirační nahlížení na „posametové - demokratické" období 90. let. Až na Kahudův román, jehož závěr je více než nejasný, nabízejí výše uvedené romány alespoň částečné, i když ne zcela uspokojivé řešení. Stefano Tani pojmenovává tento typ detekce jako „inovativní“, a je tedy jedním ze základních variant ${ }^{7}$ detektivky metafyzické, pro niž je právě kritický apel na fungování dnešní společnosti př́iznačnou vlastností. „V inovativním typu antidetektivního příběhu je řešení stále přítomno, ale je poněkud nevděčné [...] spravedlnost netriumfuje tak, jak bychom očekávali poté, co je řešení odhaleno.

7) Dalšími typy jsou dle Stefana Taniho dekonstruktivní a metatextová antidetektivka (TANI 1984: 73). 
[...] Pravidla nejsou subvertována, nýbrž zpochybněna“8 (TANI 1984: 72). Jako jeden z př́klado̊ inovativní metafyzické detekce uvádí Tani právě Ecův román Jméno růže: „Řekl bych, že Jméno růže je převážně inovativním antidetektivním románem; je zde originální prostředí, jakýsi parodický protodetektiv, volné užití konvenčních pravidel, které jsou transponovány do doby před detektivy, a dokonce také společenské a ironické zaujetí obdobím středověku, které se zdá být velmi blízké naší době z hlediska bojů o moc a pocitu krize“99 (TANI 1984: 72).

Prostřednictvím analýzy výše uvedených románů se pokusíme objasnit postupy české inovativní metafyzické detektivky, na základě podrobnějšího rozboru románu Radky Denemarkové Př́spěvek k dějinám radosti bychom se pokusili poukázat na to, jakým způsobem autorka aktualizuje a inovuje společensko-kritický detektivní román.

\section{Apelující Radka Denemarková: Příspěvek $k$ dějinám radosti}

Text Radky Denemarkové považujeme za příkladnou ukázku inovativního typu metafyzického detektivního románu - je velmi syrovým obrazem naší povrchní a netečné společnosti. V románu Příspěvek $k$ dějinám radosti na pozadí policejního vyšetřování domnělé sebevraždy vynáší na povrch často upozad’ovaný zločin páchaný na ženách dennodenně a přitom často bez potrestání viníka, znásilnění. Denemarková, která ve svých předchozích románech nepracovala s narativními schématy detektivního žánru, zde rozvíjí hned dvě detektivní linie, $\mathrm{z}$ nichž jedna ostentativně odkazuje $\mathrm{k}$ americké tradici drsné školy. Postava Policisty ${ }^{10}$ je typ detektiva, který se bezhlavě vrhá do podezřelého případu zdánlivé sebevraždy bohatého muže, porušuje zákon vloupáním se do tajemného domu, holduje alkoholu i vnadám krásné femme fatale - Vdově po zemřelém. Přestože se Policistovi podaří ve sklepení domu najít klíč k odhalení identit tří záhadných starých dam, jež po vzoru lovců nacistů Simona Wiesenthala trestají

8) „In innovative anti-detective fiction a solution is still present, although partially unrewarding [...] justice does not triumph as we automatically expect when the solution is discovered. [...] Rules are not subverted, but rather put in dubious light..."

9) „I would say that Il nome della rosa is mainly an innovative anti-detective novel; there is an original setting, a somehow parodic protodetective, a free use of conventional rules, which are transposed in a predetective fiction time, and even a social and ironical preoccupation with the portrayal of a medevial time which seems so close to our own in terms of struggles for power and the sense of crisis."

10) Denemarková záměrně neoznačuje postavu policisty konkrétním jménem. Tímto zobecněním zdůrazňuje roli postavy, podobně činí i v př́ípadě ženských postav Vdovy či Medové. 
muže, kteří znásilňují ženy, a propojit tak dvě linie detekce v jednu, ani v tomto románě nedochází $\mathrm{k}$ velkému odhalujícímu finále. Čtenář sleduje obě linie příběhu, vyprávění policisty i dam, které vzaly spravedlnost do svých rukou, a je mu proto už $\mathrm{v}$ polovině knihy motiv zápletky jasný. $\mathrm{V}$ závěru také chybí potrestání - Policista sice odhalí pachatelky, ale ukáže se jako člověk s morálními hodnotami a neudá je. Z hlediska žánru je však poražen. Osud žen zůstává nedořešený, vypravěč popisuje jejich vstup do moře, čtenář si může jen domýšlet, že patrně spáchaly společnou sebevraždu. Denemarková svou knihu sice zpracovala ve formě krimi románu, detektivní zápletka je tu však až na druhém místě. Jde především o poselství znásilněných žen. To je navíc zaobaleno do všudypřítomných metafor - at’ už vlaštovek, které na vše seshora shlíží, nebo řeči těla, jež si vše pamatuje.

Stefano Tani k inovativnímu typu metafyzické detekce poznamenává: „Racionalita (řešení) a lidskost (spravedlnost) už se neshodují. Racionální detektiv nebo tvrdý policista, který prosazuje zákon, se zdá být neschopný učinit krok od účinné racionality ke spravedlnosti, to znamená k civilnímu odhodlání a lidskému soucitu“11 (TANI 1984: 53). Otázka spravedlnosti a humánnosti je v podání Denemarkové komplikovanější, potrestání zločinců zde neabsentuje, nýbrž je naplněno nesystémovou formou, bez účasti státních institucí. Rozpravy Policisty s „mstitelkami“ spisovatelkou Birgit a lektorkou jógy Dianou čtenáři podávají nečernobílý pohled na problém vzetí spravedlnosti do vlastních rukou. Na jedné straně se Policista snaží bránit vưči jejich převrácené morálce, namítá, že zlo nelze vymýtit zlem a že svým zpo̊sobem jsou ženy vražedkyně. Na straně druhé Birgit ospravedlňuje jejich kategorické činy: „Někdy je nutné vzít spravedlnost do vlastních rukou. [...] Kdyby šlo o nacisty nebo komunisty nebo masové vrahy, tomu by se rozumělo. Kdybychom bojovaly proti teroristům, tomu by rozumělo. [...] Ale jsme jen a jen na straně obětí a tou obětí jsou znásilněná těla“ (DENEMARKOVÁ 2014: 275). Policista i přes racionální argumenty odmítá být spoluviníkem a naznačuje nezbytné udání, nakonec je ale doslova převálcován mentální silou Diany a zmateně odchází: „Policista se vypotácí z oranžového domu pod Petřínem, couvá, blekotá, že rozumí, že případ oběšeného muže uzavřel jako sebevraždu“" (DENEMARKOVÁ 2014: 285).

Podvrací Radka Denemarková ve svém románu pravidla žánru? V Příspěvku $k$ dějinám radosti je čtenář konfrontován se dvěma detekcemi. V první Policista

11) „By now, rationality (solution) and humanity (justice) do not coincide any more. The rational detective or tough policeman who enforces the law seem unable to make step from effective rationality to justice, that is, to civil commitment and human compassion." 
řeší případ sebevraždy, která se ukáže být vraždou. Ve druhé tři svérázné ženy Birgit, Diana a Erika sledují majitele uxursko-hiomské restaurace, v níž evidentně dochází ke zneužívání mladých dívek. $V$ obou případech je detekce v závěru naplněna zkonkrétněním, poskytnutím doplňujících, k plnému obrazu nezbytných informací - čtenář se dozvídá, jakým způsobem zvládly tři staré ženy pověsit statného muže, i konkrétní praktiky majitele restaurace Yusufa. Přestože čtenář mnohé tuší již dříve, určitý stupeň informační nasycenosti v závěru je zde přítomen (Birgitino doznání, respektive explicitní prozrazení Dianina umu hypnotizérské techniky). Přístup Denemarkové není subverzivní, odpovídá Taniho popisu inovativní detekce - setkáváme se s nedokonalým detektivem, jehož úsudky sice nejsou mylné, ale je zdolán druhou stranou (dobra - zla?). Řešení je určitým způsobem přítomno, ale je vưči čtenáři „nevděčné“ - výpověd” Denemarkové si musí vyložit sám. Otázek se nabízí vícero, Petr. A. Bílek se ptá: „Máme právo vstupovat do životů jiných? Má takový zásah smysl, když o to společenské nastavení nestojí? Jakým způsobem bojovat proti nespravedlnosti a násilí? (BÍLEK, P. A., 2014). Toto jsou přední otázky, které svým románem Denemarková otevírá, diskutuje se čtenářem o tom, jaké je jeho vnímání světa, jak se staví vůči medialitě zločinu. Prostřednictvím všudypřítomných ptačích metafor mimo jiné ukazuje, že vše vidíme z odstupu, z řeči, zprostředkovaně. Proto text zahrnuje konfrontačními introspekčními motivy spojenými s hudbou, jógou, řečí těla. Klára Kubíčková píše, že „detektivkou román není proto, že se stala módním žánrem, ale proto, že znásilnění je prostě zločin“"(KUBÍČKOVÁ, 2014).

Román Radky Denemarkové byl v několika recenzích interpretován z hlediska feministické kritiky. Její tři hlavní hrdinky, které se jako vlaštovky snaží pomoci svým bližním - znásilněním deformovaným ženám - se sice zastávají především žen, ale jak v jejich případě, tak v případě vypravěče, nejde o jednostranný feministický přístup. V textu najdeme esejistické vsuvky zabývající se mimo jiné i tímto tématem: „A nejhorší jsou pro mě feministky v podobě teoretických intelektuálek, které vzdálenými fakty dokládají, jak muži zlikvidovali základní lidská práva pro ženy, ale mužům ochotně přinesou pantofle a nabízejí nejen servis v kuchyni a obdiv, ale i svůj čas, myšlenky, nápady“ (DENEMARKOVÁ 2014: 165). Denemarková ani její postavy nenahlížejí negativně pouze na muže, naopak všímá si také současného fenoménu zlatokopek, připomíná, že ve válce jsou sexuálně zneužíváni i muži: „[...]v Srebrenici nutily samopaly muže, aby vykouřil péro druhému muži, tělo zradí, tělo je s dobyvateli [...] tělo vystř́íkne[...],“ (DENEMARKOVÁ 2014: 263). Fikční svět zde zabydlují i záporné ženské postavy, kupř́ikladu sociální pracovnice Štika, která nevynakládá příliš velkou snahu 
řešit problémy zneužívaných dívek, naopak tvrdí, že si za to mohou samy svým lascivním vzezřením a chováním. Zápornou postavou je také krásná, všemi obdivovaná studentka Medová, která láká své spolužačky do pasti inkriminované restaurace. Na druhou stranu ale vypravěč podotýká, že krvelační jsou v prvé řadě muži, válečné mašinérie považuje za maskulinní záležitost.

Kromě leitmotivu znásilnění se Radka Denemarková dotýká také dalšího závažného společenského tématu, který je v nynější době velmi aktuální, a to problému s přistěhovalectvím. Jednou z „oběti“ hrdinek románu je Yusuf, majitel uxursko-hiomské restaurace, která je místem kuplírství. Když je jeho obchod s nezletilými odhalen, nechápe, čím se provinil: „[...] je dobrým mužem a dobrým muslimem a dobrým člověkem a rodičům posílá peníze a vůbec nechápe tuhle bláznivou zemi, proč sem kdy lezl, ty holky přece můžou být štastné, že si jich všiml zrovna on, prostě si to jen mohly užít, vždyt jsou to jen holky[...]“ (DENEMARKOVÁ 2014: 264).

Styl psaní Radky Denemarkové je surový, nekompromisní. Vyžaduje aktivního čtenáře, pro kterého není text pouhou relaxací, ale interpretační výzvou. V krátkém teoretickém úvodu věnujícím se metafyzické detektivce jsme naznačili její částečné propojení s postmoderní literaturou. V Příspěvku k dějinám radosti tak můžeme jmenovat několik postmoderních motivů, kupříkladu Policistovo bloudění labyrintem - sklepením v domě pod Petřínem, kde nachází usvědčující dokumenty; svévolné zacházení s reálnými postavami ve fikčním světě, hru s fakty. Ovšem v případě Denemarkové se rozhodně nejedná o prvoplánově postmoderní hru s narativem. Román Příspěvek k dějinám radosti považujeme za výrazně metaforický román detekce se společensko-kritickým zaměřením odhaluje děsivé stránky člověka, jemuž okolnosti umožňují podrývat osobnost druhých. Text můžeme označit jako metafyzický detektivní román - empirie je zde podřízena ontologii, důležitější než otázka „kdo je vrah“ je naše vnímání světa a lidí v něm. Ostatně, totožnost vraha čtenář odhaluje již v průběhu vyprávění, překvapení tak tkví spíše v rozkrývání motivací. Souhlasíme s Kateřinou Kadlecovou, dle níž se jedná především o bojovný román - „angažované, aktuální společensko-kritické alegorické podobenství se závažným poselstvím“ (KADLECOVÁ, 2014: 48). Obdobným případem je román polské autorky Olgy Tokarczukové Svi̊j vioz i pluh ved' pres kosti mrtvých z roku 2010. Také Tokarczuková je nejen ve své zemi respektovanou spisovatelkou, která po velkých románech (jako je například román Běguni, 2007) přichází s detektivním žánrem, prostřednictvím něhož otevřeně kritizuje pasivní společnost ( $v$ tomto případě jde o brutální přístup člověka ke zvířeti). Také Tokarczuková nechává svou 
hrdinku Janu Dušejkovou vykonat pomstu, respektive „spravedlivý“ trest, ovšem ji samotnou spravedlnosti nevydá, zločin zůstává nepotrestán.

\section{Nostalgie Miloše Urbana: Přišla z moře}

Téma přistěhovalectví se stalo tématem i pro spisovatele Miloše Urbana, ovšem z opačné pozice. Jeho román Přišla $z$ moře vyšel ve stejném roce jako kniha Radky Denemarkové, tedy v roce 2014, kdy přistěhovalecká vlna nebyla ještě tak silná, respektive tak medializovaná. Jeho hlavní hrdina novinář Vrba je Čech pracující v Anglii, což samozřejmě nezůstalo bez komentářů ke vztahu Angličanů k cizincům, především těch ze střední a východní Evropy: „Pochopil jsem, že všichni ti muslimové a hinduisté, co si je Británie od padesátých let natahala jako služebné síly, jsou mu milejší než já nebo Polák, který mu chodí opravit ucpaný dřez. Na ty první si už zvykl“ (URBAN, 2014: 93). Karel Vrba nechce být dalším Čechem, na kterého se Angličané dívají skrz prsty, jeho snem je dostat se do vyšší společenské tř́idy, což se mu díky náhodě i intrikám nakonec podaří. Podle Romana Kandy ovšem v Urbanově případě nejde ani tak o konstruktivní kritickou reflexi s jasným cílem, jako spíše o typicky urbanovský nostalgický povzdech, tentokrát po již neexistující Anglii: „Zjištujeme, že levicově laděný sociální podtext vypravěče nudí [viz s. 176], a sám houževnatě setrvává na úrovni sebepotvrzování předsudků a nedospělého obdivu k již neexistující, zpola vysněné Anglii, zahalené do modravého hávu nostalgie“(KANDA, 2014: 3). Upozorňuje na pasáž, v níž se autor vyhraňuje vůči severským detektivkám, které mají zpravidla sociální podtext a překypují krvavými scénami. Zároveň zde Urban ospravedlňuje proměnu své poetiky - ve starších románech (Sedmikostelí, Stín katedrály, Santiniho jazyk) se velkému počtu mrtvol nebránil, nyní se vrací k „oldschoolové“ jediné vraždě (jak se o klasických detektivkách vyjadřuje postava románu, šéfredaktor Trevor - pozn. MP). Miloš Urban v rozhovoru reaguje na otázku, zda je jeho román skutečně myšlen jako odpověd' na současné severské kriminální romány, následovně: „Na rozdíl od dnešních krimiautorů si vystačím s jednou mrtvolou, a tu společenskou přidanou hodnotu navíc tam mám taky. Akorát se tu neřeší státní zřízení ani rasové nepokoje na Chomutovsku, ani kriminální podsvětí Stockholmu, kam nalezli všichni vyvrhelové z jihovýchodní Evropy. ${ }^{\text {"12 }}$ 
Pro tvorbu Miloše Urbana je společenská kritika více než příznačná, detektivní pátrání je mu zástěrkou pro vyjádření nesouhlasu hned v několika románech - v Sedmikostelí i Lordu Mordovi nostalgicky řeší problém moderního urbanismu, který je mu proti srsti ${ }^{13}$, v Santiniho jazyku ironizuje marketingové strategie, jež nebezpečně zkreslují naše vnímání světa, Hastrmanovo běsnění je zase způsobeno neúctou člověka $\mathrm{k}$ př́rodě ( $\mathrm{v}$ případě románu Hastrman se ovšem jedná o thriller). Označení metafyzický detektivní román vyhovuje pouze v případě románu Sedmikostelí - v ostatních románech detektivové neselhávají, neodmítají řešit zločin, motiv detekce, ač není v románech primární, má svůj logický začátek a konec, čtenář není ponechán v nevědomí. Naopak v Sedmikostelí se sice policista Květoslav Švach dobere k cíli, zjistí, kdo stojí za zrůdnými vraždami, ovšem v rozporuplném epilogu se přidává na stranu vrahů-ideologů. Čtenář je tak donucen řešit podobnou otázku jako u románu Radky Denemarkové - může člověk zabít pro „dobrou věc“ - ve jménu vyšších idejí? Podstatnější než identita vraha je hledání identity Květoslava - ten v románu prochází pozvolnou iniciací, která vyvrcholí jeho novou pozicí kronikáře Bratrstva Božího těla.

\section{0. léta v podání Václava Kahudy: Vítr, tma, přitomnost}

Opačným případem je opus magnum Václava Kahudy Vitr, tma, př́tomnost, na němž autor pracoval několik let. Zdálo by se až troufalé označit tento román za detektivku, vzhledem $\mathrm{k}$ tomu, že kniha aspiruje na to stát se výpovědí o generaci prvního desetiletí 21. století, podobně jako se stala zpovědí 90 . let Sestra Jáchyma Topola. Přestože se jedná především o břitkou reflexi transformace české společnosti ze socialistické na kapitalistickou, jíž doprovází řada konspiračních teorií, hnacím pohonem vyprávění je právě pátraní. Prvotní pohnutkou je snaha zjistit, co se stalo s dědečkem hlavního hrdiny, vypravěče Petra, za druhé světové války: „Už řadu let jsem přemýšlel nad náhlou a podivnou smrtí mého dědečka. Postupem času rostly a hromadily se informace, až to dostávalo obrysy úkladného činu [...]“" (KAHUDA 2014: 18). Jako úspěšný konstruktér musel čelit nátlaku nacistů, patrně po odmítnutí spolupráce náhle

13) „Jednalo se o řadu panelových domů na pražském sídlišti Opatov. Ateliér navrhl jakýsi nový protipožární systém, používající materiál vyráběný firmou, s jejímž majitelem se Barnabáš dobře znal. Systém fungoval bezvadně, ale v bloku, kde byl použit, začali umírat lidé. Na rakovinu. Včetně malých dětí. Ten blok ještě stojí, pronesl téměř neslyšně“ (URBAN, 2001: 268). 
zemřel. Počátek příběhu se tak skutečně rýsuje jako detektivka - společně s vypravěčem se čtenář ptá: kdo udal jeho dědečka? Na jakém tajném projektu dědeček pracoval? Byl skutečně záměrně otráven, jak se domníval jeho syn? Holmesovskou dedukci však Kahuda brzy utne a přejde k poeticko-konspirační reflexi novodobých dějin. „Hrdinova cesta začíná v klasických archivech, ale brzy je svedena do vnitřního vesmíru, do registrů paměti,“ dodává ve své recenzi příznačně pojmenované Kratochvilná historie profízlovaného Česka podávaná prózou Ivan Adamovič (ADAMOVIČ 2016). Motiv detekce je ovšem stále přítomný - hrdina se snaží odhalit hlavní hybatele společnosti, což jsou podle něj především tajné služby. Pátrání po síti jejich kontaktů tak tvoří jádro knihy vypravěč hledá tajné agenty a zpovídá je, pátrá jak na internetu, tak i ve vlastní paměti. Získané výpovědi, informace i vzpomínky mu pak dávají příležitost k jízlivé kritice společnosti, na niž nahlíží jako na neustálý proces spiknutí. Vytahuje mnohá tabu spojená s československými politickými elitami a „dostává na papír to nejodpornější z našich novodobých dějin“ (BĚLíČEK, 2016). Pomocí těchto cest se vypravěč pokouší v podstatě o nemožné - zjistit, na jakém principu je postaveno fungování našeho světa. Hlavnímu hrdinovi se podaří dostat do blízkosti exkluzivního informačního zdroje Borise Pankina (respektive - unese jej), s nímž komunikuje za pomoci DMT. Vypravěč se opět vrací k záhadnému úmrtí svého dědy, avšak vše odhalující finále se nekoná. Halucinační rozuzlení, které Ivanu Adamoviči připomíná americký film Počátek, nepřináši žádné nové informace. Podobně jako Pynchon i Kahuda nechává svého čtenáře v tmách - pokud se jedná o osud dědečka hlavního hrdiny, zůstáváme i na konci románu v podobné situaci, jako jsme byli na začátku. Autorovi jde ovšem o něco jiného - a to je zásadní pro metafyzické detektivní vyprávění všeobecně - román nemá být jednoduše kauzální, měl by fungovat jako poselství vypovídající o úloze člověka na tomto světě: „Všechny naše činy a kroky říkají, lidstvo dosáhlo limitů svého druhu. Nová, planetární bytost musí mít kooperativní soucitné ego. Musí být prostá etnických a živočišných pudových složek - které vedou k násilím a válkám“ (KAHUDA 2014: 713). V tomto ohledu svůj závěrečný postoj autor nabízí.

Román Václava Kahudy náleží ke druhému typu metafyzické detektivky, jak jej definuje Stefano Tani. Jedná se o dekonstruktivní metafyzickou detektivku, pro níž je charakteristické především ambiguidní vnímání reality z pohledu detektiva. Detektiv není schopen podat svou interpretaci vnějších okolností, je spíše tvưrcem mystérií, nežli jejich řešitelem. Nenachází objektivní vysvětlení - detektiv se ponořuje hlouběji do vlastní identity a získává poznatky sám 
o sobě. Konfrontace tak neprobíhá mezi detektivem a vrahem, nýbrž detektivem a realitou či detektivovou myslí a jeho identitou (TANI 1984:77). Společenská kritika může být $\mathrm{v}$ dekonstruktivním typu stále přítomna, ale je nasycena konspirativním výkladem naší reality (TANI 1984: 78). Kahudův román tomuto Tanimu pojetí dekonstruktivní metafyzické detektivky, jež se opírá o známé postmoderní romány jako Dražba série č. 49 Thomase Pynchona nebo Falling Angel Williama Hjortsberga, víceméně vyhovuje. Na dějiny Kahuda pohlíží jako na sled konspirací tajných služeb, dochází k mnoha „odhalením“ či alternativním výkladům historie. Je si zaručeně jist, jak to bylo s útěkem bratři Mašínů, který měl být posvěcen Státní bezpečností, podobně s přehledem líčí atentát na amerického prezidenta Kennedyho. Výpovědi mohou na některé čtenáře působit dozajista spekulativně či paranoidně, nicméně v mnoha př́ipadech se opírají o uvěřitelné informace. To potvrzuje i Adamovič: „Není ovšem snadné po sedmi stech stranách [...] nebýt infikovaný autorovým pohledem. A pak se najednou přestaneme lecčemu divit. Prezident Zeman jako kdyby jednal podle pokynů Kremlu a při výročí 17. listopadu 1989 v roce 2014 bývalí estébáci vyprávějí, jak měli Havla obtočeného kolem prstu a jak se vše odehrávalo pod taktovkou KGB. [...] Autorovo tvrzení, že celé Česko je taková písnička, kterou si píská ruský medvěd, začne získávat poněkud méně paranoidní ráz" (ADAMOVIČ 2016). Společenská kritika je v Kahudově spektru nahlížena z makro hlediska, nesoustředí se na jeden konkrétní problém, nýbrž na podstatu fungování současné společnosti. Podle Jana Bělíčka se dokonce Kahuda staví do pózy „spisovatele-mesiáše, který se snaží a světlo vytáhnout pravdu o současnosti“ (BĚLíčEK 2014: 16).

\section{Smělý přistup Patrika Ouředníka: Ad acta}

Dekonstruktivní přístup k žánru zaujal také český literát působící ve Francii Patrik Ouředník. V roce 2006 vydal krátkou, ale velmi smělou prózu tvářící se jako detektivka, jak napovídá i název. Desítky let odkládaný př́ípad vraždy je dokonce jen jednou z detektivních linií, k řešení vybízí také nejasná sebevražda, případ znásilnění nebo žhářství. Snaha čtenáře držet krok s literárním hrdinou detektivem Lebedou je ovšem negována jednak neaktivním přístupem Lebedy a jednak dezinformacemi vypravěče. Ten čtenáři nijak nenapomáhá, naopak jej zaplavuje množstvím falešných stop a zlomyslně mu zatajuje ty podstatné. Ad acta souzní s Taniho popisem dekonstruktivní detekce jako textu, který 
ve čtenáři zanechává dojem, že mrhal svým časem, při snaze poodhalit tajemství bezvýznamných klíčů je ponechán ve tmě. Ouředník do této své prózy sice ukryl jakési detektivní puzzle, jeho řešení je ale pouze intuitivní a v textu není přítomno. $\mathrm{V}$ doslovu knihy Jean Montenot připomíná, že Ouředníkův román „navíc končí událostí, která celou záhadu de facto obnovuje, a nutí čtenáře, aby přehodnotil své dosavadní hypotézy“ (MONTENOT 2012). ${ }^{14}$ Patrik Ouředník zde záměrně zpřevrátil přehledný svět detektivek, které v člověku zanechávají iluzi, že každý problém má své řešení. Ouředník se tímto románem přibližuje realitě, v níž některé „životní situace a počiny zůstanou navždy bez logického vysvětlení, navždy nepochopitelné či přinejmenším nezřetelné pro pouhý rozum“ (MONTENOT 2012). Nelogicky strukturovaný text navíc doplňuje jazykový nonsens, absurdní diskuse, vyprázdněná reklamní hesla. Lingvistická hra je pro Ouředníka podstatnější rovinou vyprávění nežli detekce. Prostřednictvím jazyka poukazuje na nesmyslná lidská konání, „vyprahlé životy v panoptikálně zvrhlé době“ (STANĚK 2007). Jazyk je také nositelem kritiky společnosti - hlavní postava románu Viktor Dyk je povahou misantrop, který neustále velmi ostrým způsobem komentuje českou společnost, respektive pranýřuje tak zvané čecháčkovství. Glosuje kupříkladu typické přisvojování si úspěšných lidí: „Většina lidí, kteří to ve světě někam dotáhli, byli ostatně českého původu: Sigmund Freud, Madelaine Albrightová et passim“ (OUŘEDNÍK 2006: 17). Jak prázdné rozhovory postav, tak i ironické narážky vypravěče upozorňují na pokrytecké vztahy mezi lidmi, udavačství a sobectví. Někteři čeští recenzenti považovali autorův styl za samoúčelnou exhibici ${ }^{15}$, my se naopak ztotožňujeme s názorem francouzského spisovatele Erica Chevillarda, který se ve své interpretaci pro deník Le Monde napsal, že „dokola omílané dialogy, neustálá hra s jazykovými klišé z této knihy činí komickou rozvahu o jazyce, který je zároveň jediným prostředkem, jenž nám pomáhá uchopit realitu“. ${ }^{16}$

\section{Závěrem}

Rysy metafyzické detekce, tak jak byly popsány výše, bychom mohli nalézt i v dílech z první poloviny 20. století. Vezmeme-li v potaz konkrétně českou

14) Doslov Jeana Montenota k francouzskému vydání Ad acta (Classé sans suite, nakl. Allia, 2012) vyšel pod názvem „Libre suite à Classé sans suite“. Česky in Souvislosti 1, 2012. Přeložila Olga Špilarová.

15) Kazimír Turek v Lidových novinách, Pavel Mandys v Týdnu.

16) Citováno dle MONTENOT 2012. 
literaturu, jíž se zabýváme primárně, nelze nezmínit Karla Čapka, jenž byl velkým obhájcem detektivního žánru, který dokázal současně inovovat. Vývoj metafyzického detektivního žánru si jistě zaslouží pozornost, v této studii jsme se ovšem zaměřili na jednu konkrétní oblast, a to na české romány, které jednak inovativně pracují s detekcí a jednak jsou společensky angažovaná. Výše uvedené romány dokládají značnou různorodost v oblasti české transformace detektivního žánru po roce 1989. Jedná se o práce respektovaných autorů, pro něž je detektivní syžet jednorázovým nástrojem. Soustavněji přispívají k transformaci detektivního žánru jen někteří z nich - Miloš Urban, Roman Ludva nebo Jan Jandourek, ovšem pouze v tvorbě Miloše Urbana je společensko-kritický apel konstantním vyjadřovacím prostředkem. Pomocí detektivní literatury útočí na zkorumpovanou městskou politiku a její následky (Sedmikostelí 1998, Lord Mord 2008) či na praktiky kapitalistické společnosti, jejíž jediným cílem je „prodat“ (Santiniho jazyk 2005). Přestože raná díla Miloše Urbana literární kritici často uváděli v souvislosti s tvorbou Umberta Eca, nejsou jeho romány právě ukázkovými příklady metafyzické detekce. Urbanovy texty protínají mnohá popkulturní klišé, závěry románů nabízejí spíše zjednodušená překotná řešení, nežli enigmatický příslib. V české literatuře se metafyzický detektivní román nejpregnantněji představuje v díle Michala Ajvaze (Prázdné ulice 2004, Cesta na jih 2008), u něhož je však kritika současné společnosti přítomna pouze nezáměrně (ironický postoj k ovlivňování lidské mysli médii, zahlcování společnosti kýčem). Do kontextu společensko-kritického románu detekce nám nejlépe zapadá román Radky Denemarkové Přispěvek $k$ dějinám radosti z roku 2014. Text ostentativně pracuje s detektivním žánrem a zároveň, v duchu metafyzické detekce, podrývá jeho zásady. Současně se autorka neobává otevřeně kritizovat laxní společnost, jež v zásadě nijak nebojuje proti sexuálnímu násilí na ženách. Početné př́iklady uvedené v této krátké studii ukazují, že detektivní žánr i v současné literatuře funguje jako dobrý komunikační prostředek mezi čtenářem a spisovatelem, jenž chce upozornit na nesrovnalosti ve společnosti. Syžet založený na detekci je čtenářsky vděčný a spisovateli poskytuje příležitost šírit své myšlenky (kupříkladu společensko-kritické) širšímu publiku. Zároveň je právě detektivní žánr velmi dobře transformovatelný a lze jej kreativně infiltrovat do recepčně náročnější literatury. 
Michaela Paučo

Společensko-kritické aspekty české metafyzické detektivky

\section{PRAMENY}

AJVAZ, Michal

2008 Cesta na jih (Brno: Druhé město)

BORGES, Jorge Luis

1999 Nesmrtelnost (Praha: Hynek)

DENEMARKOVÁ, Radka

2014 Př́spěvek k dějinám radosti (Brno: Host)

ECO, Umberto

1988 Jméno růže (Praha: Odeon)

FUKS, Ladislav

1983 Vévodkyně a kuchařka (Praha: Československý spisovatel)

KAHUDA, Vladimír

2014 Vitr, tma, prítomnost (Brno: Druhé město)

RYWIKOVÁ, Nela

2013 Dưm číslo 6 (Brno: Host)

STANČÍK, Petr

2014 Mlýn na mumie (Brno: Druhé město)

SÝKORA, Martin

2013 Modré stíny (Brno: Host)

ŠKVORECKÝ, Josef

1991 Mirákl (Praha: Atlantis)

TOKARCZUKOVÁ, Olga

2010 Svưj vưz i pluh ved" pres kosti mrtvých (Brno: Host)

TUČKOVÁ, Kateřina

2012 Žitkovské bohyně (Brno: Host)

URBAN, Miloš

1999 Sedmikosteli (Praha: Argo)

2014 Přišla z moře (Praha: Argo)

OUŘEDNíK, Patrik

2006 Ad Acta (Praha: Torst) 


\section{LITERATURA}

ADAMOVIČ, Ivan

2016 „Kratochvilná historie profízlovaného Česka podávaná prózou“, in Iliteratura.cz. Dostupné zde: http://www.iliteratura.cz/Clanek/36109/kahuda-vaclav-vitr-tma-pritomnost, cit. 18. 5. 2018

BĚLÍČEK, Jan

2014 „Vnitřnosti sametové revoluce“, A2, č. 16,. Dostupné z: https://www.advojka.cz/archiv/2014/16/ vnitrnosti-sametove-revoluce, cit. 3. 4. 2018

BÍLEK, Petr A.

2014 „Tohle už není náš svět“, Respekt. Dostupné z: http://www.respekt.cz/tydenik/2014/41/tohle-uzneni-nas-svet, cit. 6. 5. 2018

GOMEL, Elana

„Mystery, Apocalypse and Utopia: The Case of the Ontological Detective Story“, Science Fiction Studies 22(3), s. 343-356

HOLQUIST, Michael

1971 „Whodunit and Other Questions: Metaphysical Detective Stories in Post-War Fiction," New Literary History, Modernism and Postmodernism: Inquiries, Reflections, and Speculations, vol. 3, no. 1, s. 135-136

KADLECOVÁ, Kateřina

2014 „Bitevní pole Žena“, Reflex, 30. 10., s. 48

KANDA, Roman

2014 „Splendid isolation“, Tvar, č. 13, s. 3

KUBÍČKOVÁ, Klára

2013 „Nela Rywiková snad ukáže své skutečné kvality v př́íśí knize“, Idnes. Dostupné z: https://kultura. zpravy.idnes.cz/nela-rywikova-recenze-0u8-/literatura.aspx?c=A130607_162138_literatura_ob, cit. 12. 5. 2018

2014 „Znásilněníje těžké téma pro román. Denemarková to zvládá“, Idnes. Dostupné z: https://kultura.zpravy.idnes.cz/radka-denemarkova-prispevek-k-dejinam-radosti-fov-/literatura.aspx?c=A141012_122609_ literatura_vha, cit. 13. 5. 2018

MANDYS, Pavel

2006 „Hra na schovávanou“, Týden, č. 48, s. 82

MCHALE, Brian

1987 Postmodernist Fiction (Londýn: Routledge)

MERIVALE Patricia, SWEENEY Susan Elizabeth

1999 Detecting Texts. The Metaphysical Detective Story from Poe to Posmodernism (University of Pensylvania: University of Pensylvania Press) 
Michaela Paučo

Společensko-kritické aspekty české metafyzické detektivky

MERIVALE, Patricia

1967 „The Flaunting of Artifice in Vladimir Nabokov and Jorge Luis Borges“, in Contemporary Literature

Vol. 8, No. 2, pp. 294-309. Dostupné z: https://www.jstor.org/stable/1207107, cit. 15. 5. 2018

MONTENOT, Jean

2012 „Ad acta, ad arbitum“, in Souvislosti 1. Dostupné z: http://www.nllg.eu/spip.php?article840, cit. 8. 4. 2018

\section{PETŘÍČEK, Miroslav}

2000 Majestát zákona: Raymond Chandler a pozdní dekonstrukce (Praha: Herrmann \& synové)

SPANOS, William V.

1972 „The Detective and the Boundary: Some Notes on the Postmodern Literary Imagination“, Boundary Vol. 2 1, 1, s. 147-168

STANĚK, Jan

2007 „Zapomenutá vražda“, Host, č. 3. Dostupné z: http://www.nllg.eu/spip.php?article677, cit. 6. 4. 2018

\section{TANI, Stefano}

1984 The Doomed Detective. The Contribution of the Detective Novel to Postmodern American and Italian Fiction (Southern Illinois University: Southern Illinois University Press)

TUREK, Kazimír

2006 „Patrik Ouředník, Ad acta“, Lidové noviny, č. 272, s. 6

Mgr. Michaela Paučo, 368230@mail.muni.cz, Ústav české literatury a knihovnictví, Filozofická fakulta, Masarykova univerzita, Brno, Česká republika / Department of Czech Literature and Library Studies, Faculty of Arts, Masaryk University, Brno, Czech Republic 